\title{
Pelatihan Penulisan Artikel Ilmiah dan Publikasi di Jurnal bagi Guru SMAN 4 Tualang, Kabupaten Siak
}

\author{
Marwa $^{1}$, Marta Dinata ${ }^{2}$ \\ 1, 2 Universitas Lancang Kuning, Indonesia
}

\begin{abstract}
A B S T R A C T
WRITING SCIENTIFIC ARTICLES AND PUBLICATIONS TRAINING IN JOURNALS FOR TEACHERS OF SMAN 4 TUALANG, SIAK REGENCY. The training of the article writing and journal publication was held in SMAN 4 Tualang, Kabupaten Siak-Riau due to teachers' problems covering the lack of article writing knowledge, low motivation and awareness of the importance of conducting research and its dissemination particularly for teachers' professional development. Moreover, the teachers did not know much about journals information whereby they could publish their article writing. Therefore, the outreach community team from Faculty of Education and Teachers' training, Universitas Lancang Kuning Pekanbaru conducted this program in order to solve the teachers' problems. This training was conducted in one day (8 hours) consisting of two sessions. In the first session (8-12 a.m.), the participants were given the materials about the essence, elements, and knowledge of article writing followed by making article draft (how to make a good title, abstract and introduction). In the second session (1-5 p.m.), the trainer gave materials pertaining to how to deal with publication process from registration, login, and article online submission in journals. The simulations were given as the trainer guided the participants to register to ELT Lectura FKIP Unilak Journal, Bio-Lectura Journal, and Lectura: Journal Pendidikan UNILAK, login, check and read information in the journals. In short, this training facilitated the SMAN 4 Tualang teachers' knowledge and skills of article writing and they know how to publish their articles. The outreach team suggests future outreach community program conduct the same activity since there are many school teachers need the training of article writing and publication in journals.
\end{abstract}

Keywords: Article, Journal, Publication.

\begin{tabular}{llll}
\hline Received: & Revised: & Accepted: & Available online: \\
26.09 .2019 & 11.01 .2020 & 03.02 .2020 & 14.02 .2020 \\
\hline
\end{tabular}

\section{Suggested citation:}

Marwa., \& Dinata, M. (2020). Pelatihan penulisan artikel ilmiah dan publikasi di jurnal bagi guru SMAN 4 Tualang, Kabupaten Siak. Jurnal Pengabdian Pada Masyarakat, 5(1), 71-82. https://doi.org/10.30653/002.202051.256

Open Access I URL: http://ppm.ejournal.id/index.php/pengabdian/article/view/256

${ }^{1}$ Corresponding Author: Program Studi Pendidikan Bahasa Inggris, FKIP Universitas Lancang Kuning, Pekanbaru; Jl. Yos Sudarso KM. 08, Rumbai, Pekanbaru, Indonesia; Email: marwaoke@yahoo.co.id 


\section{PENDAHULUAN}

Secara umum diketahui bahwa jumlah publikasi penelitian di Indonesia di tingkat berkala ilmiah masih sangat rendah. Penyebab utama dari kelemahan ini adalah budaya membaca dan menulis yang merupakan aspek penting dalam penelitian belum berkembang di masyarakat Indonesia pada umumnya dan di perguruan tinggi pada khususnya. Keadaan ini juga disebabkan oleh rendahnya kemauan dan kemampuan menuliskan hasil-hasil penelitian maupun pengabdian kepada masyarakat dalam berkala bermutu oleh para peneliti yang semestinya secara kontinyu dilakukan oleh para guru dan dosen di ruang lingkup dunia akademik. Akibatnya, penyebaran hasilhasil penelitian dan pengabdian kepada masyarakat melalui berkala ilmiah nasional dan internasional tidak dapat dikembangkan dan dimenfaatkan secara maksimal untuk peningkatan taraf hidup masyarakat. Karena itulah, pengembangan budaya dan kemampuan menulis menjadi suatu tantangan ataupun merupakan permasalahan yang harus segera diatasi. Merujuk kepada undang-undang, maka perlu diingat bahwa UU Nomor 20 Tahun 2003 tentang Sistem Pendidikan Nasional, menegaskan bahwa pendidik adalah tenaga professional yang bertugas merencanakan dan melaksanakan proses pembelajaran menilai hasil pembelajaran, melakukan pembimbing dan pelatihan, serta melakukan penelitian dan pengabdian kepada masyarakat.

Tentu saja salah satu pihak yang mesti berperan besar dalam mengembangkan budaya menulis ilmiah yang menghasilkan kontribusi dan inovasi ilmu pengetahuan adalah guru. Guru adalah pendidik professional dengan tugas utama, mendidik, mengajar, membimbing, mengarahkan, melatih, menilai, dan mengevaluasi peserta didik pada pendidikan anak usia dini jalur pendidikan formal, pendidikan dasar, dan pendidikan menengah (Undang-Undang Nomor 14 Tahun 2005 tentang Guru dan Dosen). Oleh sebab itu, kualitas profesionalisme guru ditunjukkan oleh lima sikap, yakni: (1) keinginan untuk selalu menampilkan perilaku yang mendekati standar ideal; (2) meningkatkan dan memelihara citra profesi; (3) keinginan untuk senantiasa mengejar kesempatan pengembangan profesional yang dapat meningkatkan dan memperbaiki kualitas pengetahuan dan ketrampilannya; (4) mengejar kualitas dan citacita dalam profesi; (5) memiliki kebanggaan terhadap profesinya (Sagala, 2009).

Menyikapi kualitas profesionalisme guru, maka salah satu upaya yang mesti dilaksanakan oleh guru-guru dalam pengembangan keprofesian berkelanjutan adalah ikut ambil bagian dalam publikasi ilmiah baik dari dari hasil penelitian ilmiah maupun dari hasil gagasan ilmu bidang pendidikan formal. Selanjutnya, karya tulis ilmiah guru dapat ditulis berdasar pada pengalaman dan sesuai dengan tugas pokok serta fungsi guru dan dapat dipublikasikan dalam bentuk laporan hasil penelitian atau laporan/gagasan ilmiah (Kementerian Pendidikan Nasional, Direktorat Pembinaan Pendidik dan Tenaga Kependidikan, Buku 4: 2011).

Karya tulis ilmiah adalah suatu karya yang memuat dan mengkaji suatu masalah tertentu dengan menggunakan kaidah-kaidah keilmuan. Menurut Prayikno (2001) kaidah keilmuan yang dimaksud bahwa karya ilmiah menggunakan metode ilmiah di dalam membahas permasalahan, menyajikan kajian dengan menggunakan bahasa baku dan tata tulis ilmiah, serta menggunakan prinsip-prinsip keilmuan yakni bersifat objektif, logis, empiris, sistematis, lugas, jelas dan konsisten. Karya tulis ilmiah yang harus ditulis oleh guru untuk mengembangkan diri dan harus dipublikasikan kepada 
masyarakat sebagai bentuk kontribusi guru terhadap peningkatan kualitas proses pembelajaran di sekolah dan pengembangan dunia pendidikan secara umum dan untuk memperoleh angka kredit sesuai dengan Peraturan Menteri Negara Pendayagunaan Aparatur Negara dan Reformasi Birokrasi Nomor 16 Tahun 2009 tentang Jabatan Fungsional Guru dan Angka Kreditnya adalah publikasi ilmiah.

Selanjutnya, Direktorat Jenderal Pendidikan Tinggi, Kementerian Pendidikan dan Kebudayaan (2014) menginisiasikan penyelenggaraan Pelatihan Penulisan Artikel Ilmiah Internasional bagi para peneliti produktif. Ini merupakan salah satu upaya yang dilakukan untuk mengatasi persoalan-persoalan yang ada di lapangan dengan melakukan pelatihan penulisan artikel ilmiah baik untuk berkala nasional terakreditasi maupun pada berkala ilmiah bereputasi internasional. Tentu saja kegiatan ini diharapkan akan dapat memicu dan memacu para peneliti produktif dalam hal ini masyarakat akademik untuk mempublikasikan hasil-hasil penelitiannya dalam artikel ilmiah pada berkala ilmiah bereputasi internasional. Menurut Subekti (2015) situs olahan pemeringkatan publikasi ilmiah SCImago (www.scimagojr.com) telah memeringkatkan hasil publikasi 239 negara dan Indonesia berada pada urutan ke-61. Bahkan peringkat publikasi Indonesia kalah jauh dibandingkan dengan negara-negara ASEAN lainnya (Malaysia, Singapura dan Thailand). Berdasarkan fakta tersebut, diperlukan langkah-langkah konkrit untuk menggesa peningkatan publikasi artikel ilmiah yang didahului dengan penelitian dan penulisan artikel yang berkualitas serta berpotensi untuk terbit di jurnal-jurnal nasional dan internasional bereputasi.

Merujuk pada fakta tentang kondisi tingkat publikasi Indonesian yang rendah, maka perlu ditegaskan kembali kepada guru-guru dan dosen-dosen peneliti untuk menggesa karya tulisan ilmiah mereka. Untuk itu, pemerintah membuat aturan kenaikan pangkat dengan cara menuntut publikasi ilmiah guru-guru sebagai syarat penting dan wajib ada. Untuk itu, Karya tulis ilmiah harus ditulis oleh guru untuk mengembangkan diri dan harus dipublikasikan kepada masyarakat sebagai bentuk kontribusi guru terhadap peningkatan kualitas proses pembelajaran di sekolah dan pengembangan dunia pendidikan secara umum dan untuk memperoleh angka kredit sesuai dengan Peraturan Menteri Negara Pendayagunaan Aparatur Negara dan Reformasi Birokrasi Nomor 16 Tahun 2009 tentang Jabatan Fungsional Guru dan Angka Kreditnya adalah publikasi ilmiah.

Sekolah Menengah Atas Negeri (SMAN) 4 Tualang Siak merupakan sekolah yang berdiri pada tahun 2013 di daerah kecamatan Tualang, kabupaten Siak. Untuk mempercepat kemajuan sebuah sekolah, dibutuhkan sumber daya manusia yang berkualitas dan berkemampuan akademik unggul. Karena itu keberadaan guru-guru profesional yang mampu mengembangkan ilmunya khususnya dalam bidang penelitian untuk menghasilkan artikel ilmiah yang kemudian dipublikasikan sangat diperlukan. Di samping hal ini dapat menunjang mutu sekolah dalam pencapaian akreditasi A, guru-guru yang rajin menulis karya ilmiah secara nyata telah menjadi guru-guru yang profesional dan tentu saja mampu bersaing dengan dengan guru-guru SMA profesional lainnya. Salah satu syarat sekolah yang memiliki daya saing yaitu memiliki guru yang profesional dan kompeten di bidang keilmuan masing-masing. Menurut SK bersama Menteri Pendidikan Nasional dan Kepala Badan Administrasi Kepegawaian Negara no 0433/P/1993 dan no 25 tahun 1993: seorang guru selain 
menjalankan tugas pokoknya mengajar, juga dituntut untuk melakukan berbagai kegiatan seperti melaksanakan penelitian lapangan, menulis bahan ajar, makalah dan lain sebagainya. Di dunia akademik, seorang guru dinyatakan profesional apabila memiliki sertifikat guru profesional. Salah satu syarat penting untuk lulus sertifikasi guru dan juga untuk kenaikan pangkat maka guru-guru diwajibkan untuk melakukan penelitian dan menghasilkan artikel ilmiah yang harus dipublikasikan di jurnal-jurnal nasional maupun internasional.

Di SMAN 4 Tualang Siak terdapat guru-guru muda yang baru mengembangkan diri untuk menjadi guru-guru profesional yang bukan saja bertugas untuk mentransfer ilmunya kepada siswa akan tetapi juga melaksanakan kewajiban lainnya yaitu berpartisipasi dalam pengembangan IPTEK bagi kesejahteraan masyarakat. Oleh karena itu, merujuk kepada amanah Tri Darma Perguruan Tinggi pada kegiatan pengabdian masyarakat, maka sangat diprioritaskan bagi guru-guru SMAN 4 Tualang untuk diberi pelatihan penulisan artikel ilmiah yang berpotensi publikasi di jurnal. Hal ini bertujuan untuk meningkatkan kemampuan dan eksistensi guru-guru di SMAN 4 Tualang Siak dalam meningkatkan mutu dan professional guru sebagai seorang pendidik dan peneliti. Pelatihan ini dimaksudkan untuk memperbaiki serta meningkatkan kemampuan guru dalam memhasilkan karya tulis ilmiah dari hasil penelitian mereka.

\section{METODE}

\section{Prosedur Kegiatan}

Metode pelaksanaan kegiatan pengabdian kepada masyarakat ini dilakukan berdasarkan langkah-langkah seperti analisis situasi, identifikasi masalah sekolah mitra, metode ceramah, metode diskusi, metode tutorial individu dan kelompok.

Analisis Situasi: digunakan untuk observasi lapangan dan wawancara kepada kepala sekolah dan guru-guru di sekolah mitra tentang pengetahuan dan pengalaman mereka tentang penulisan artikel ilmiah.

Idetifikasi Masalah: digunakan untuk mengidentifikasi permasalahan mitra untuk dicarikan solusinya. kurangnya pengetahuan tentang kaedah-kaedah penulisan artikel ilmiah, rendahnya kesadaran guru terhadap pentingnya meneliti dan menghasilkan karya tulis ilmiah yang berpotensi publikasi bagi profesi guru, minimnya pengetahuan guru tentang jurnal-jurnal ilmiah dimana mereka dapat menerbitkan artikel/karya tulis mereka, dan belum adanya media/rumah jurnal di lingkungan akademik mereka yang dapat mempublikasikan karya ilmiah guru baik yang cetak maupun yang online.

Metode Ceramah: digunakan untuk memberikan pemahaman kepada para peserta tentang topik pengabdian yaitu pelatihan penulisan artikel ilmiah dan publikasi di jurnal. Dalam ceramah diuraikan kerangka materi secara, jelas, mudah dipahami, dan aplikatif. Metode ceramah dalam pelatihan ini diusahakan untuk menghindari pembahasan teoritis yang berlarut-larut dan lebih menekankan pada contoh-contoh kasus beserta pemecahannya. Penyajian materi pengabdian dilanjutkan dengan tanya jawab dan diskusi. 
Metode Diskusi: dipilih untuk lebih memberikan kesempatan kepada para peserta membahas, mempertanyakan, menggarisbawahi, memberi masukan, dan atau memperdalam materi yang diceramahkan. Metode ini diberi porsi waktu yang lebih banyak daripada ceramah.

Metode Tutorial Individual atau Kelompok ini dipilih untuk melengkapi pemahaman tentang suatu materi yang telah diceramahkan dan didiskusikan dengan mengaplikasikan secara langsung untuk memperbaiki (menyunting) naskah ilmiahnya masing-masing dengan diberi pendampingan. Pendekatan dalam metode ini adalah learning by doing dengan pendampingan.

\section{Peserta dan Lokasi Kegiatan}

Kegiatan pengabdian ini dilaksanakan pada tanggal 25 Juli 2019. Peserta dalam kegiatan pengabdian masyarakat ini adalah guru-guru di SMAN 4 Tualang Siak. Jumlah peserta yang akan mengikuti pelatihan diperkirakan sebanyak 25 orang guru. Kemudian, kegiatan pelatihan ini akan dilaksanakan di SMAN 4 Tualang Siak (di ruang Aula sekolah).

\section{HASIL DAN PEMBAHASAN}

\section{Hasil Pengabdian Kepada Masyarakat}

Kegiatan Pengabdian kepada masyarakat yaitu "Pelatihan Penulisan Artikel Ilmiah Dan Publikasi Di Jurnal Bagi Guru-Guru Sman 4 Tualang Kabupaten Siak" yang melibatkan mitra guru-guru di SMAN 4 Tualang dilaksanakan dalam beberapa tahapan. Kegiatan pertama yaitu tim pelaksana melakukan tahap analisis situasi berupa observasi lapangan dan wawancara kepada Kepala Sekolah dan wakil Kepala sekolah bidang kurikulum SMAN 4 Tualang tentang pengetahuan guru-guru dalam penulisan artikel ilmiah dan publikasi di jurnal. Setelah itu tim pelaksana pengabdian mengidentifikasi permasalahan mitra pengabdian untuk dicarikan solusinya. Akhirnya tim pelaksana memutuskan untuk memberikan pelatihan penulisan artikel ilmiah kepada guru-guru SMAN 4 Tualang Siak.

\section{Kegiatan Sebelum Pelatihan}

Pada hari Kamis 25 Juli 2019 (pukul 8.00-17.00 WIB), kegiatan pengabdian kepada masyarakat yaitu pelatihan penulisan artikel ilmiah dilaksanakan dengan dihadiri oleh 18 orang peserta guru dan 5 orang siswa perwakilan OSIS. Sebelum pemberian materi dan pelatihan, pemateri (Dr. Marwa, M.A) memberikan sebuah angket tentang persepsi peserta sebelum mendapatkan pelatihan penulisan karya ilmiah dan publikasi di jurnal yang terdiri dari 9 pernyataan dan satu pertanyaan: (1) Guru membutuhkan pelatihan penulisan karya ilmiah dan publikasi di jurnal ilmiah, (2) Pelatihan tentang penulisan karya ilmiah merupakan kebutuhan semua guru mata pelajaran/bidang studi, (3) Peserta (guru) sudah memahami tentang langkah-langkah dalam penulisan karya tulis ilmiah sebelumnya, (4) Peserta (guru) sudah pernah mengikuti pelatihan penulisan karya tulis ilmiah, (5) Sekolah menyediakan cukup waktu untuk memberikan bimbingan dan kesempatan mengikuti pelatihan penulisan karya tulis ilmiah 
sebelumnya, (6) Materi tentang penulisan karya tulis ilmiah sudah pernah diberikan di sekolah bagi guru-guru, (7) Media yang ada di sekolah membantu guru untuk memahami tentang penulisan karya tulis ilmiah dan publikasi di jurnal ilmiah, (8) Peserta memiliki pengetahuan yang cukup tentang penulisan karya tulis ilmiah dan publikasi di jurnal ilmiah, (9) Penulisan karya tulis ilmiah merupakan hal penting yang harus dilakukan guru-guru sekolah, (10) Jika dilakukan pelatihan/sosialasi serupa, materi apa yang paling anda harapkan?

Hasil analisa angket yang diberikan sebelum pelatihan menunjukkan tingkat persepsi dan pemahaman guru tentang penulisan artikel ilmiah dan publikasi. Berikut adalah rujukan skala rataan hitung dan kategori skor (Katz \& Kahn, 1978) dan hasil analisa Rataan Hitung dari angket yang diberikan kepada guru bahasa Inggris sebelum pelatihan.

Tabel 1. Skala Rataan Hitung Angket dan Kategori

\begin{tabular}{l}
\hline $\begin{array}{l}\text { No Skala Rataan Hitun } \\
\text { (Range of maen score) }\end{array}$ \\
\hline $11.00-2.49$ Low \\
$22.50-3.99$ Moderate \\
$34.00-5.49$ High
\end{tabular}

Sumber: Katz \& Kahn (1978)

Tabel 2. Hasil Analisa Angket Peserta Sebelum Pelatihan

\begin{tabular}{llllllllll}
\hline No & Nama & SS & S & N & KS & TS & Total & Mean & Kategori \\
\hline 1 & Guru 1 & 0 & 16 & 12 & 2 & 1 & 31 & 3,4 & Moderate \\
2 & Guru 2 & 0 & 12 & 18 & 0 & 0 & 30 & 3,3 & Moderate \\
3 & Guru 3 & 0 & 20 & 16 & 0 & 0 & 36 & 4 & High \\
4 & Guru 4 & 0 & 12 & 18 & 0 & 0 & 30 & 3,3 & Moderate \\
5 & Guru 5 & 0 & 16 & 15 & 0 & 0 & 31 & 3,4 & Moderate \\
6 & Guru 6 & 0 & 20 & 16 & 0 & 0 & 36 & 4 & High \\
7 & Guru 7 & 0 & 8 & 21 & 0 & 0 & 29 & 3,2 & Moderate \\
8 & Guru 8 & 0 & 8 & 21 & 0 & 0 & 29 & 4,1 & Moderate \\
9 & Guru 9 & 25 & 0 & 12 & 0 & 0 & 37 & 4,6 & High \\
10 & Guru 10 & 30 & 12 & 0 & 0 & 0 & 42 & 4,6 & High \\
11 & Guru 11 & 30 & 0 & 12 & 0 & 0 & 42 & 4,1 & High \\
12 & Guru 12 & 15 & 16 & 6 & 0 & 0 & 37 & 3,6 & High \\
13 & Guru 13 & 10 & 16 & 3 & 4 & 0 & 33 & 3,3 & Moderate \\
14 & Guru 14 & 15 & 8 & 0 & 6 & 1 & 30 & 4,5 & Moderate \\
15 & Guru 15 & 25 & 16 & 0 & 0 & 0 & 41 & 3,6 & High \\
16 & Guru 16 & 15 & 0 & 18 & 0 & 0 & 33 & 3,6 & Moderate \\
17 & Guru 17 & 15 & 0 & 18 & 0 & 0 & 33 & 3,6 & Moderate \\
18 & Guru 18 & 15 & 24 & 0 & 0 & 0 & 39 & 4,3 & High \\
\hline & Total & 195 & 204 & 206 & 12 & 2 & 619 & 3,8 & Moderate \\
\hline
\end{tabular}

Berdasarkan Tabel 2 dapat disimpulkan bahwa persepsi guru-guru tentang esensi, substansi, pengetahuan, pengalaman dalam penulisan artikel ilmiah dan publikasi 
jurnal dikategorikan moderate atau sedang dengan hasil rataan kelompok 3,8 dari 18 orang guru. Data ini menunjukkan bahwa guru-guru SMAN 4 Tualang kabupaten Siak masih memerlukan pelatihan untuk mengupgrade pengetahuan dan pengalaman mereka dalam menulis dan mempublikasikan artikel ilmiah.

\section{Kegiatan Pelatihan Penulisan Artikel Ilmiah dan Publikasi di Jurnal}

Tim pelaksana pengabdian melaksanakan kegiatan berikutnya yaitu penyampaian materi pelatihan mulai pukul 8.30-17.00 WIB. Pada sesi ini Dr. Marwa, M.A. mempresentasikan materi (ppt) tentang komponen artikel ilmiah hasil penelitian yang terdiri dari pembahasan tentang (1) Judul, (2) Penulis, (3) Abstrak \& Kata Kunci, (4) Pendahuluan, (5) Metode, (6) Hasil, (7) Pembahasan, (8) Simpulan, dan (9) Daftar Rujukan. Tiap-tiap komponen artikel ilmiah tersebut dijelaskan oleh pemateri secara jelas dan detail. Untuk memudahkan pemahaman peserta pelatihan, pemateri memberikan penjelasan bahwa secara populer, sistematika paparan isi artikel hasil penelitian biasa dikelompokkan dalam akronim IMRaD (Introduction, Method, Result, and Discussion).

Adapun materi pelatihan penulisan karya ilmiah dan publikasi di jurnal yang diberikan kepada peserta adalah sebagai berikut:

1) Judul harus informatif mencerminkan isi artikel secara konseptual, memuat variabel atau konsep yang dicakup dalam artikel, tempat pelaksanaan penelitian tidak dicantumkan dalam judul, tempat pengumpulan data tidak dicantumkan dalam judul, hindari rumusan judul yang bernuansa kelembagaan.

2) Nama Penulis harus ditulis tanpa disertai gelar akademik, mesti ada nama lembaga asal penulis disertai alamat untuk korespondensi (alamat surat atau e-mail penulis), sponsor (ucapan terima kasih) di catatan kaki pada halaman pertama di catatan akhir sebelum daftar rujukan.

3) Abstrak ringkas dan padat (dalam 1 alinea) tentang ide-ide yang paling penting, abstrak memuat: masalah dan/atau tujuan penelitian, prosedur penelitian, ringkasan hasil penelitian, simpulan. Abstrak ditulis dalam bahasa Inggris untuk bisa diakses sehingga memperoleh peluang untuk disitasi. Menurut UU tentang Bahasa, abstrak juga harus ditulis dalam bahasa Indonesia, kata kunci memuat kata-kata konseptual, dan jumlah kata kunci sekitar 3-5.

4) Pendahuluan biasanya tidak diberi judul memuat latar belakang atau konteks penelitian, landasan teori (jika diperlukan), hasil kajian pustaka yang menunjukkan adanya kesenjangan temuan penelitian, wawasan rencana pemecahan masalah dan/atau kontribusi keilmuan yang "dijanjikan", rumusan tujuan penelitian.

Bagian pendahuluan yang berisi paparan tentang konteks penelitian yang bernuansa kelembagaan (misalnya: tentang IKIP yang menjadi universitas) perlu diubah menjadi paparan konseptual tentang resistensi terhadap inovasi dan didukung oleh temuan penelitian sebelumnya tentang resistensi terhadap inovasi apapun di berbagai belahan dunia. Bagian pendahuluan artikel untuk jurnal diakhiri dengan alinea yang berisi masalah penelitian yang dirumuskan dalam bentuk tujuan penelitian, persis sebelum paparan bagian metode penelitian.

5) Metode secara ringkas dalam paragraf-paragraf memuat (tidak harus secara eksplisit; tidak harus diberi sub-judul): desain/prosedur penelitian, populasi \& 
sampel/sumber data, alat/instrument \& bahan yang digunakan, bagaimana data dikumpulkan, dan bagaimana data dianalisis.

6) Hasil berisi paparan hasil analisis menjawab pertanyaan penelitian, hasil bersih analisis data, hasil pengujian hipotesis dan dapat disajikan dengan tabel atau gambar selain penyajian secara verbal untuk memperjelas. Oleh karena itu, jawaban terhadap semua pertanyaan penelitian ditulis dalam bagian ini; tabel harus berisi hasil analisis secara ringkas dan bermakna yang langsung dapat dipahami pembaca tidak boleh ada data mentah yang ditampilkan dalam tabel tabel tidak diberi garisgaris vertikal, dan garis horisontal hanya atas dan bawah saja.

7) Pembahasan adalah bagian terpenting dari keseluruhan isi artikel ilmiah. Bagian pembahasan berisi: Pemaknaan/penafsiran hasil analisis data, membandingkan dengan hasil-hasil temuan penelitian sebelumnya, pengintegrasian hasil-hasil penelitian ke dalam kumpulan pengetahuan yang telah mapan, penyusunan teori baru atau modifikasi teori yang ada dan implikasi hasil penelitian

8) Kesimpulan memuat jawaban atas pertanyaan penelitian dalam bentuk substantif, atau memaparkan inti sari hasil pembahasan dalam bentuk esai, bukan dalam bentuk numerikal. Bagian ini memuat pernyataan hubungan antara fenomena/variabel/faktor yang mengarah pada pengembangan teoretis. Simpulan yang baik adalah yang selalu diingat oleh penelitinya tanpa harus baca lagi rumusannya.

9) Daftar rujukan lengkap sesuai dgn yang diacu dalam teks: semua yang dirujuk dalam teks masuk ke daftar rujukan, semua yang ada dalam daftar rujukan memang dirujuk dalam teks, lebih banyak menggunakan pustaka primer (hasil penelitian) dan mutakhir (10 tahun terakhir), tatacara penulisan daftar rujukan mengikuti gaya selingkung yang berlaku di jurnal yang bersangkutan.

Oleh karena itu, kualitas rujukan ditandai dengan terpenuhinya tiga kriteria: Relevansi dengan bidang ilmu yang diteliti, kemutakhiran sumber pustaka (minimal $80 \%$ terdiri atas pustaka yang terbit 10 tahun terakhir), dan keprimeran, sebaiknya yang dimuat dalam jurnal bereputasi (minimal jumlahnya $80 \%$ ).

Kegiatan pemaparan materi disampaikan oleh pemateri diselingi dengan sesi tanya jawab dan diskusi dengan para peserta. Pemateri juga meminta data dari peserta berupa judul penelitian yang pernah dilakukan oleh mereka. Para peserta menuliskan judul penelitian S1 mereka dan fakta yang ditemukan bahwa para peserta tidak pernah mempunyai artikel yang dipublikasikan. Kemudian pemateri menyarankan mereka untuk segera merancang hasil penelitian S1 mereka dalam format artikel ilmiah seperti yang sudah dijelaskan oleh pemateri. Peserta pelatihan membuat draft judul artikel, nama penulis, menentukan kata kunci dalam abstrak dan kerangka pendahuluan serta mendiskusikan draft tersebut dengan pemateri. Pemateri juga memberikan contoh sebuah artikel yang sudah dipublikasikan dan membedah artikel tersebut menurut urutan komponen sebuah artikel ilmiah. Kegiatan ini bertujuan untuk memberikan penjelasan dan latihan yang lebih konkrit tentang bagaimana menuliskan hasil penelitian dalam bentuk artikel ilmiah.

Selanjutnya, pemateri juga memberikan penjelasan tentang rumah jurnal dan tujuan dari penerbitan sebuah jurnal. Adapun tujuan menerbitkan jurnal yaitu untuk meregistrasi kegiatan kecendekiaan, menyertifikasi hasil kegiatan yang memenuhi 
persyaratan ilmiah, mendiseminasikannya secara meluas kepada khalayak ramai, dan mengarsipkan semua temuan hasil kegiatan kecendekiaan ilmuwan yang dimuatnya. Pemateri juga meginformasikan tentang rumah jurnal yang dimiliki oleh Fakultas Keguruan dan Ilmu Pendidikan Universitas Lancang Kuning seperti Bio-Lectura FKIP Unilak, ELT-Lectura FKIP Unilak dan Lectura: Jurnal Pendidikan FKIP Unilak yang semuanya telah terakreditasi. Pemateri juga menjelaskan ke peserta pelatihan bagaimana untuk registrasi ke jurnal tersebut agar bisa login, submit artikel dan lainlain. Informasi tentang jurnal nasional terakreditasi SINTA (rangking 1-6) dan journal internasional terindeks Scopus (Q1-Q4), EBSCO dan lembaga pengindeks lainnya juga diberikan kepada para peserta dengan tujuan memberikan wawasan kepada mereka tentang rumah jurnal untuk publikasi karya tulis ilmiah.

Setelah pemaparan materi dan diskusi dilaksanakan, para peserta mulai memahami bagaimana cara menulis artikel ilmiah sesuai dengan kaedah dan mereka juga mengetahui bagaimana melakukan proses publikasi mulai dari registrasi dan membuat akun di sebuah jurnal, login ke jurnal dan kirim artikel untuk publikasi.

\section{Kegiatan Setelah Pelatihan}

Setelah melaksanakan kegiatan pelatihan dengan memberikan materi dibarengi dengan diskusi dengan peserta serta memberikan penugasan membuat draft judul artikel, nama penulis, menentukan kata kunci dalam abstrak dan kerangka pendahuluan, pemateri (Dr. Marwa, M.A) memberikan sebuah angket tentang persepsi peserta sesudah mendapatkan pelatihan penulisan karya ilmiah dan publikasi di jurnal yang terdiri dari 10 pernyataan: (1) Guru membutuhkan pelatihan penulisan karya ilmiah dan publikasi di jurnal ilmiah, (2) Pelatihan tentang penulisan karya ilmiah merupakan kebutuhan semua guru mata pelajaran/bidang studi, (3) Setelah mengikuti kegiatan ini, peserta (guru) lebih memahami tentang penulisan karya ilmiah, (4) Kegiatan pelatihan penulisan karya ilmiah membantu guru dalam mempublikasikan penelitian, (5) Pemateri atau narasumber menyediakan cukup waktu untuk memberikan pelatihan, bimbingan dan kesempatan bertanya untuk peserta, (6) Materi yang disampaikan selama kegiatan pelatihan mudah dimengerti oleh peserta, (7) Media yang digunakan instruktur sangat membantu peserta dalam memahami materi pelatihan penulisan karya tulis ilmiah, (8) Durasi penyampaian materi dan bimbingan pelatihan sudah cukup ideal, (9) Penyampaian materi tentang penulisan karya ilmiah oleh narasumber mampu menarik minat peserta, (10) Pelatihan serupa dibutuhkan oleh guru pada tingkatan sekolah yang berbeda, misalnya pada level SD atau SMP.

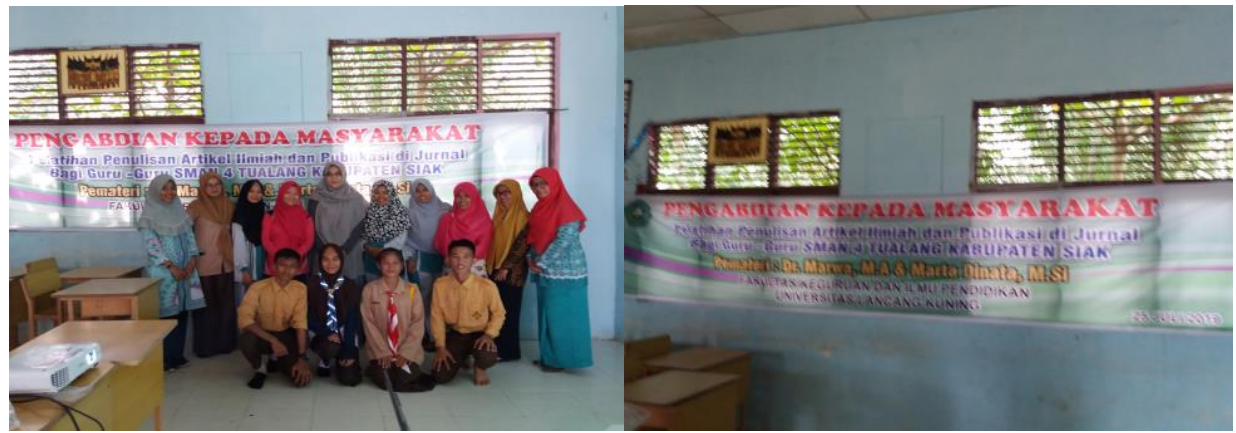

Gambar 1. Tim Pengabdian dan Peserta 
Tabel 3. Hasil Analisa Angket Peserta Setelah Pelatihan

\begin{tabular}{llllllllll}
\hline No & Nama & SS & S & N & KS & TS & Total & Mean & Kategori \\
\hline 1 & Guru 1 & 5 & 32 & 3 & 0 & 0 & 40 & 4,0 & High \\
2 & Guru 2 & 30 & 16 & 0 & 0 & 0 & 46 & 4,6 & High \\
3 & Guru 3 & 5 & 36 & 0 & 0 & 0 & 41 & 4,1 & High \\
4 & Guru 4 & 5 & 36 & 0 & 0 & 0 & 41 & 4,1 & High \\
5 & Guru 5 & 35 & 12 & 0 & 0 & 0 & 47 & 4,7 & High \\
6 & Guru 6 & 30 & 16 & 0 & 0 & 0 & 46 & 4,6 & High \\
7 & Guru 7 & 5 & 20 & 12 & 0 & 0 & 37 & 3,7 & Moderate \\
8 & Guru 8 & 15 & 24 & 3 & 0 & 0 & 42 & 4,2 & High \\
9 & Guru 9 & 30 & 16 & 0 & 0 & 0 & 46 & 4,6 & High \\
10 & Guru 10 & 10 & 32 & 0 & 0 & 0 & 42 & 4,2 & High \\
11 & Guru 11 & 15 & 28 & 0 & 0 & 0 & 43 & 4,3 & High \\
12 & Guru 12 & 25 & 20 & 0 & 0 & 0 & 45 & 4,5 & High \\
13 & Guru 13 & 20 & 24 & 0 & 0 & 0 & 44 & 4,4 & High \\
14 & Guru 14 & 25 & 20 & 0 & 0 & 0 & 45 & 4,5 & High \\
\hline & Total & 255 & 332 & 180 & 0 & 0 & 605 & 4,3 & High \\
\hline
\end{tabular}

Berdasarkan Tabel 3 yang merupakan hasil analisa angket setelah kegiatan pelatihan dapat disimpulkan bahwa persepsi guru-guru tentang esensi, substansi, pengetahuan, pengalaman, fasilitas pendukung dan trainer menulis dalam penulisan artikel ilmiah dan publikasi jurnal sangat diperlukan. Hal ini ditunjukan dengan hasil rataan hitung sebesar 4,3 dan dikategorikan dalam level "High" atau "Tinggi" dari responden 14 orang guru. Data ini menunjukkan kegiatan pelatihan penulisan artikel ilmiah dan publikasi di jurnal ini memberikan kontribusi positif pada aspek pengetahuan dan pengalaman bagi guru-guru SMAN 4 Tualang kabupaten Siak. Para peserta menyadari bahwa menulis sebuah artikel memerlukan pengetahuan yang matang dan usaha aktif mulai dari proses membuat draft, merevisi berulang-ulang hingga proses submit ke sebuah jurnal, revisi dari reviewer hingga dipublikasikan. Secara keseluruhan tim kegiatan pengabdian dapat menyimpulkan bahwa kegiatan pelatihan penulisan artikel ilmiah dan publikasi di jurnal bagi guru-guru dapat meningkatkan pengetahuan, pemahaman serta pengalaman mereka dalam menulis dan upaya untuk mempublikasikan tulisan mereka di jurnal-jurnal ilmiah

\section{SIMPULAN}

\section{Kesimpulan}

Dari pelaksanaan kegiatan pengabdian masyarakat yang telah dilaksanakan, tim pelaksana dapat menyimpulkan bahwa guru-guru SMAN 4 Tualang Siak sangat memerlukan pengetahuan tentang penulisan artikel ilmiah dan publikasi di jurnal. Pada sesi awal kegiatan dapat disimpulkan bahwa persepsi guru-guru tentang esensi, substansi, pengetahuan, pengalaman dalam penulisan artikel ilmiah dan publikasi jurnal dikategorikan dalam level "moderate" atau "sedang" dengan hasil rataan hitung kelompok sebesar 3,8 dari 18 orang guru. Hal ini menunjukkan bahwa guru-guru 
SMAN 4 Tualang kabupaten Siak masih memerlukan pelatihan untuk menningkatkan pengetahuan dan pengalaman mereka dalam menulis dan mempublikasikan artikel ilmiah.

Setelah pemaparan materi dan diskusi dilaksanakan, para peserta mulai memahami bagaimana cara menulis artikel ilmiah sesuai dengan kaedah dan mereka juga mengetahui bagaimana melakukan proses publikasi mulai dari registrasi dan membuat akun di sebuah jurnal, login ke jurnal dan kirim artikel untuk publikasi. Pada akhir sesi kegiatan pelatihan, dapat disimpulkan bahwa persepsi guru-guru tentang esensi, substansi, pengetahuan, pengalaman, fasilitas pendukung dan bantuan trainer/narasumber dalam penulisan artikel ilmiah dan publikasi jurnal sangat penting dan diperlukan. Hal ini ditunjukkan dengan hasil rataan hitung angket yang meningkat menjadi 4,3 dan dikategorikan dalam level "High" atau "Tinggi" dari responden 14 orang guru. Data ini menunjukkan kegiatan pelatihan penulisan artikel ilmiah dan publikasi di jurnal ini memberikan kontribusi positif pada aspek pengetahuan dan pengalaman bagi guru-guru SMAN 4 Tualang kabupaten Siak.

\section{Saran}

Berdasarkan kesimpulan di atas, perlu diadakan pelatihan penulisan karya ilmiah dan publikasi di jurnal bagi guru-guru di semua level baik gguru SD, SMP, dan SMA sederajat. Kegiatan ini sangat penting untuk dilaksanakan secara berkelanjutan mengingat bahwa kegiatan ini merupakan tuntutan wajib bagi para guru sebagaimana yang diatur oleh undang-undang tentang angka kredit dan kenaikan pangkat/jabatan fungsional bagi guru. Salah satu faktor atau syarat penentu adalah guru punya publikasi ilmiah. Tim pengabdian menyarankan agar dinas pendidikan secara serius memberikan perhatian dan pembinaan yang bersifat terstruktur dan sistematis mengingat ada beberapa kesulitan yang dihadapi oleh guru-guru dalam memenuhi tuntutan publikasi diantaranya faktor motivasi, waktu, teknik penulisan, gagap teknologi, ketersediaan referensi, maraknya jasa penulisan karya tulis (joki), dan kurang berfungsinya musyawarah guru mata pelajaran (MGMP). Untuk tim penelitian dan pengabdian berikutnya juga masih harus memberikan atensi terhadap pembinaan guru-guru dalam menulis dan mempublikasikan artikel ilmiah mereka.

\section{REFERENSI}

Kementerian Pendidikan Nasional RI. (2011). Pedoman Pengelolaan Pengembangan Keprofesian Berkelanjutan. Jakarta: Kementerian Pendidikan Nasional Direktorat Pembinaan Pendidikan dan Tenaga kependidikan.

Kementerian Pendidikan dan Kebudayaan RI. (2014). Panduan Pelatihan Penulisan Artikel Ilmiah Internasional. Seminar Bandung, 22-24 Oktober 2014. Direktorat Penelitian dan Pengabdian kepada Masyarakat Direktorat Jenderal Pendidikan Tinggi Kementerian Pendidikan dan Kebudayaan. 
Kementerian Pendayagunaan Aparatur Negara dan Reformasi Birokrasi. (2009). Peraturan Menteri Negara Pendayagunaan Aparatur Negara dan Reformasi Birokrasi Nomor 16 Tahun 2009 Tentang Jabatan Fungsional Guru dan Angka Kreditnya. Jakarta: Kementerian Pendayagunaan Aparatur Negara dan Reformasi Birokrasi.

Prayitno, J. H. (2001). Pembudayaan penulisan karya ilmiah. Surakarta: Muhammadiyah University Press.

Sagala, H. S. (2009). Kemampuan profesional guru dan tenaga kependidikan. Bandung: Alfabeta.

SK bersama Menteri Pendidikan Nasional dan Kepala Badan Administrasi Kepegawaian Negara no. 0433/P/1993 dan no. 25 tahun 1993.

Subekti, N. B. (2015). ranking publikasi ilmiah internasional Indonesia. Retrieved June 5, 2019 from https://osf.io/preprints/hz6e7/

Undang-Undang RI Nomor 62 Tahun 2013 tentang Sertifikasi Guru.

Undang-Undang RI Nomor 14 Tahun 2005 Tentang Guru dan Dosen.

Undang-Undang RI Nomor 20 Tahun 2003 Tentang Sistem Pendidikan Nasional.

\section{Copyright and License}

This is an open access article distributed under the terms of the Creative Commons Attribution 4.0 International License, which permits unrestricted use, distribution, and reproduction in any medium, provided the original work is properly cited. (C) 2020 Marwa, Marta Dinata. 